\title{
The Effect of Tree Species on the Chemical Properties of Soil in the Rehabilitation of a Limestone Quarry at Athi River, Kenya
}

\author{
Gathuru Gladys \\ Department of Environmental Sciences, School of Environmental Studies, Kenyatta University, Nairobi 43844-00100, Kenya
}

\begin{abstract}
A comparison of field performance of Acacia xanthophloea, Schinus molle, Casuarina equisetifolia and Gravellia robusta plant species was made in an exhausted limestone quarry, backfilled with limestone mine waste in a semi-arid area in Athi River, Kenya. The aim of the study was to determine if the tree species had an influence on the soil chemical properties. The soil had alkaline $\mathrm{pH}$ ranging from 8.0 to 8.98 , low nitrogen content $(<0.03 \%)$, moderate phosphorus concentrations ranging from $44.15 \mathrm{ppm}$ to $21.33 \mathrm{ppm}$ and high to moderate exchangeable cations ( $\mathrm{Na}, \mathrm{Ca}, \mathrm{Mg}$ and $\mathrm{K}$ ). All the tree species exerted a positive influence on soil properties necessary for plant growth. The $\mathrm{pH}$ values and total phosphorus were relatively lower in soils close to the trees $(0.5 \mathrm{~m})$ and increased with distance from the trees, while the soil values for total nitrogen and exchangeable cations were relatively higher close to the trees. $C$. equisetifolia had the best growth performance and a higher positive influence on the soil chemical properties necessary for plant growth followed by $A$. xanthophloea. It was concluded that trees should remain a feature of quarry rehabilitation because of their role in maintaining the biophysical environment.
\end{abstract}

Key words: Mining, soils chemical properties, rehabilitation, tree species, limestone quarry.

\section{Introduction}

Quarrying for limestone is an economic necessity that is not only hazardous to human but also one that invariably has deleterious effect on the environment. Quarrying is the essential first step in cement production process because limestone must be extracted from below the ground surface to provide the construction industry's raw material. However, what remains after the extraction is a large sterile quarry that in most cases does not support any life [1].

In Kenya, the traditional opencast mining in Athi River, which is a semi-arid area near Nairobi, has cleared all vegetation and disrupted the ecosystem [2-4].

The resultant impacts include alteration of landscape, uneven topography, loss of soil fertility, surface crusting and soil erosion [5].

Corresponding author: Gladys Gathuru, Ph.D., research field: environmental rehabilitation and geosciences.
The quarries have sharp drops and the area consists of few thorny acacia trees and is covered with huge waste dumps from mining operations.

Rehabilitation programmes have been tried in various parts of the world as a means of restoration of the land after mining so that its value is similar or greater than it was before the disturbance [6]. Although unassisted processes of natural colonization can deliver fully developed and functional ecosystems, they require very long times or may not be successful [7, 8]. For these reasons, restoration of mine wasteland often requires active human intervention to achieve rehabilitation within a reasonable timeframe.

Soil improvement is important in habitat restoration of mining and related disturbed lands. The reconstitution and management of a suitable soil layer to support vegetation in the long run is a crucial phase of landscape rehabilitation [4, 9]. The inadequacies in the soil components can frustrate revegetation attempts. 
Experimentation has been undertaken at mine sites around the world to attempt to elucidate and overcome limitations to vegetation establishment, allowing large-scale revegetation schemes to be formulated [10]. However, such schemes have often been successful at specific sites, and their widespread application is limited owing to the great variation in physical, chemical and biological factors which exist between mine wastes [11]. Information on the performance of trees species and its influence on the soil chemical properties over time is important as plants are key in the revegetation.

In this study, four tree species, Acacia xanthophleas, Casuarina equisetifolia, Schinus molle and Gravellia robusta were selected as having fast growth and able to reproduce under severe conditions [12-15].

\section{Methodology}

The study area is approximately $15 \mathrm{~km}^{2}$ and situated in Athi river, Machakos County, Kenya, approximately $30 \mathrm{~km}$ south-east of Nairobi. It lies between latitude $1^{\circ} 26^{\prime} 46^{\prime \prime} \mathrm{S}$ and $1^{\circ} 32^{\prime} 10^{\prime \prime} \mathrm{S}$ and is bounded by the longitudes $36^{\circ} 58^{\prime} 24^{\prime \prime} \mathrm{E}$ and $37^{\circ} 03^{\prime} 08^{\prime \prime}$ $\mathrm{E}$, at an altitude of 1,500 metres above sea level. The soil is black cotton clay with a high content of sand [16].

The mean annual temperatures range between $18{ }^{\circ} \mathrm{C}$ to $26{ }^{\circ} \mathrm{C}$ with average annual rainfall of 450 to 900 $\mathrm{mm}$. The area is characterized by low moisture content with a low to medium plant growth potential. The 'Athi Basin' is underlain by metamorphosed sequences of Pre-Cambrian gneisses, quartzites and surbodinate limestone. The formation of kunkur is a late phase in the weathering cycle associated with the concentration of carbonates in solution and its precipitation as nodules in clay [17].

\subsection{Field Experimental Designs}

The exhausted quarry was filled with the mine waste material and leveled. Four rows, five metres apart were created in blocks A, B, C and in each row
20 holes measuring $40 \mathrm{~cm} * 40 \mathrm{~cm} * 40 \mathrm{~cm}$ each were dug, one metre apart as shown in Fig. 1. All the 80 holes were filled with water to condition the surrounding soil before planting six-month old seedlings of each species in different rows using the RCBD (Randomised Complete Block Design).

The sequence of planting the four species in rows in each block was varied as illustrated in Fig. 2. Block D, the control, was left unplanted. The trees were planted in an east-west direction to minimize the shading effect [18], and watered twice weekly for the first 3 months and then twice a month for one year.

\subsection{Soil Sampling}

Soil samples were collected before planting the trees, and thereafter every six months after planting

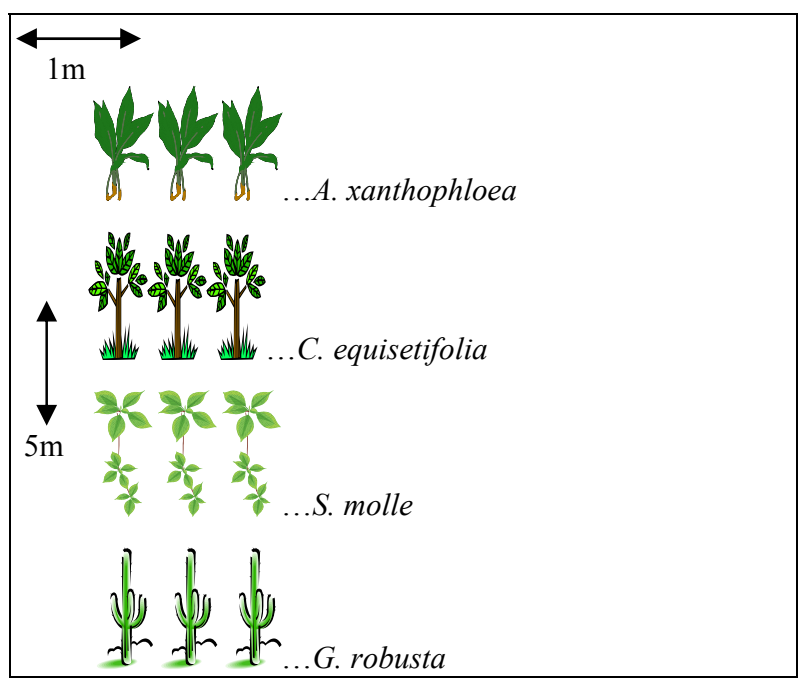

Fig. 1 Experimental layout showing within the block design.

\begin{tabular}{|l|l|}
\hline Block A & Block B \\
\hline A. xanthophloea & S. molle \\
\hline G. robust & A. xanthophlea \\
\hline S. molle & C. equisetifolia \\
\hline C. equisetifolia & G. robusta \\
\hline
\end{tabular}

\begin{tabular}{|l|l|}
\hline Block C & Block D \\
\hline C. equisetifolia & \\
\cline { 1 - 1 } S. molle & \multirow{2}{*}{ Control } \\
\cline { 1 - 1 } G. robusta & \\
\cline { 1 - 1 } A. xanthophlea & \\
\cline { 1 - 2 }
\end{tabular}

Fig. 2 Experimental layout of species planted in blocks $A$, $B$ and C. Block D was left unplanted for control. 
for a period of two years. Soil samples were collected using an auger, from depths of $0-15 \mathrm{~cm}, 15-30 \mathrm{~cm}$ and $30-45 \mathrm{~cm}$ horizons at distances of $0.5 \mathrm{~m}$ and $2.0 \mathrm{~m}$ from the planted tree row. The horizons represented part of the soils where most roots are present and most nutrients absorption occur [19]. Soil from the control was collected randomly in the same manner.

The $\mathrm{pH}$ of soil suspension was done using a Jenway pH meter Model 3510. Exchangeable $\mathrm{Na}$ and $\mathrm{K}$ were determined by Flame Photometry model number BWB-XP. Atomic Absorption Spectrophotometer PG Instrument Limited, UK, model number PG-990 was used to determine the concentrations of exchangeable $\mathrm{Ca}$ and $\mathrm{Mg}$. Soil phosphorus was measured by the method described by Olsen, S. R. and Sommers, L. E. [20]. Organic nitrogen was converted to ammonium ion by digestion with sulphuric acid followed by sodium hydroxide hydrolysis. The free ammonia was distilled off and nesslerised. A grating monochromator (Model, CE 2343D) was used to measure the colour intensity.

\section{Results and Discussion}

3.1 Chemical Composition and Fertility Status of the Material Used to Fill the Quarry

Soils chemical analysis and nutrient content for samples taken after backfilling the quarry and before planting are shown in Table 1. It was observed that the soils in the study area have on average, alkaline $\mathrm{pH}$ values (8.99), low organic matter content $(0.0474 \%)$, low total nitrogen $(0.005 \%)$ and low soil moisture content $(0.028 \%)$, but soil phosphorus was moderately present $(44.15 \mathrm{ppm})$. The soils also have high to moderate exchangeable bases ( $\mathrm{Ca}, \mathrm{Mg}, \mathrm{K}$ and $\mathrm{Na}$ ), but low manganese and zinc concentrations. The soil values were compared to by the standard of tropical soils [21,22] and show similar characteristics to calcareous soils [23].

\subsection{Tree Species Growth Rate}

By the end of the observation period, C. equisetifolia gained significant $(\mathrm{p}<0.001)$ maximum height $(525.3$ $\mathrm{cm})$ followed by $S$. molle $(305.8 \mathrm{~cm})$, A. xanthophloea $(267.2 \mathrm{~cm})$ and $G$. robusta $(231.7 \mathrm{~cm})$. ANOVA (Analysis of Variance) for tree height revealed that a time-species interaction was significant $(p<0.001)$, indicating continuous tree growth for all the species. At the end of year 2, growth rates for tree height was significantly $(\mathrm{p}<0.001)$ higher for $C$. equisetifolia (11.36 cm/month), followed by A. xanthophloea (6.73 $\mathrm{cm} /$ month), S. molle $(1.41 \mathrm{~cm} /$ month) and G. robusta $(1.35 \mathrm{~cm} /$ month $)$ as shown in Fig. 3.

\subsection{Tree Species Influence on the Soil Chemical Properties}

Chemical analysis carried out during the present

Table 1 Soils chemical analysis and nutrient content for soil samples taken within the $0-30 \mathrm{~cm}$ horizon, after backfilling the quarry and before planting.

\begin{tabular}{llll}
\hline Analysis & Value & Remark & Recommended levels \\
\hline $\mathrm{pH}$ & 8.98 & Alkaline & $6.3-7.5$ \\
Total nitrogen (\%) & 0.005 & Low & $0.2-0.5$ \\
Organic matter (\%) & 0.047 & Low & $1.72-3.43$ \\
Phosphorus (ppm) & 44.15 & Moderate & $20-80$ \\
Calcium (me \%) & 70.13 & High & $2.0-15$ \\
Magnesium (me \%) & 8.43 & High & $1.0-3.0$ \\
Sodium (me \%) & 8.89 & Moderate & $0.0-2.0$ \\
Potassium (me \%) & 3.66 & Moderate & $0.2-1.5$ \\
Manganese (me \%) & 1.86 & Low & $5-9$ \\
Iron (ppm) & 19.33 & Moderate & $>10$ \\
Zinc (ppm) & 4.25 & Low & $>5$ \\
Copper (ppm) & 8.06 & Moderate & $>1$ \\
Moisture (\%) & 0.626 & Low & \\
\hline
\end{tabular}




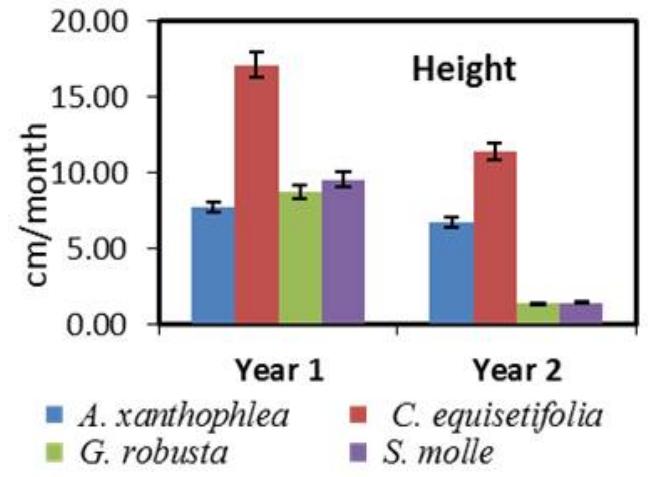

Fig. 3 Growth rate during the two-year period after planting. The vertical bars represent standard error of the mean.

study revealed particular significant effects in soil chemical attributes.

\subsubsection{Soil $\mathrm{pH}$}

At $0.5 \mathrm{~m}$ from the tree line and $0-15 \mathrm{~cm}$ horizon, the $\mathrm{pH}$ value in soils under $A$. xanthophloea had reduced from 8.98 to 8.00 ; for C. equisetifolia from 8.98 to $8.03 ;$ S. molle from 8.98 to 8.31 and G. robust from 8.98 to 8.54 . A species effect on $\mathrm{pH}$ was apparent ( $\mathrm{p}<0.01$ ), with values being relatively lower in soils under A. xanthophloea (8.0) and C. equisetifolia (8.03). The species-distance interaction was not significant but the $\mathrm{pH}$ values were relatively lower in soils close to the tree row $(0.5 \mathrm{~m})$ and increased with distance from the trees as illustrated in Fig. 4.

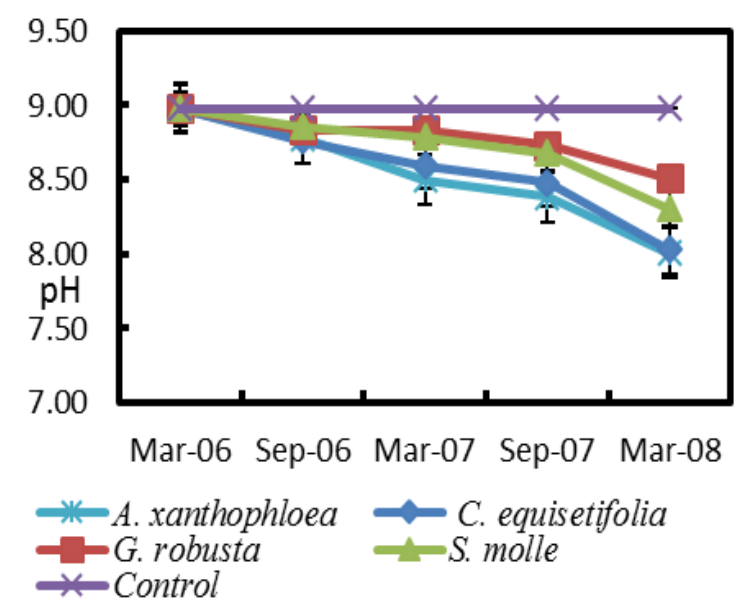

(a) $0.5 \mathrm{~m}$
Mean soil $\mathrm{pH}$ for all horizon, did not vary significantly between species but was lower in the upper horizon and again showed similar trends, under A. xanthophloea and C. quisetifolia which recorded lower $\mathrm{pH}$ values than $\mathrm{pH}$ values under G. robusta and S. molle as shown in Fig. 5.

The relatively lower $\mathrm{pH}$ values recorded in the soils collected from under A. xanthophloea and $C$. equisetifolia, than under the other tree species suggests that the presence of trees may have had a moderate acidifying effect on soils close to the trees, which probably may have been attributable to the formation of organic acids and release of carbon dioxide due to litter decomposition. Since A. xanthophloea and $C$. equisetifolia are leguminous trees, they would predominantly accumulate more nutrients within their biomass than G. robusta and S. molle. This would probably result in better growth and hence an increase in soil organic matter. Greater nitrification rates and nitrate leaching have also been reported to contribute to reductions in soil $\mathrm{pH}$, as both processes may cause acidification $[24,25]$. The significant difference in soil $\mathrm{pH}$ under the various tree species examined may also indicate that the decomposition rate of their litter differs, as the addition of organic matter is known to reduce soil $\mathrm{pH}[22,26]$. The result obtained may

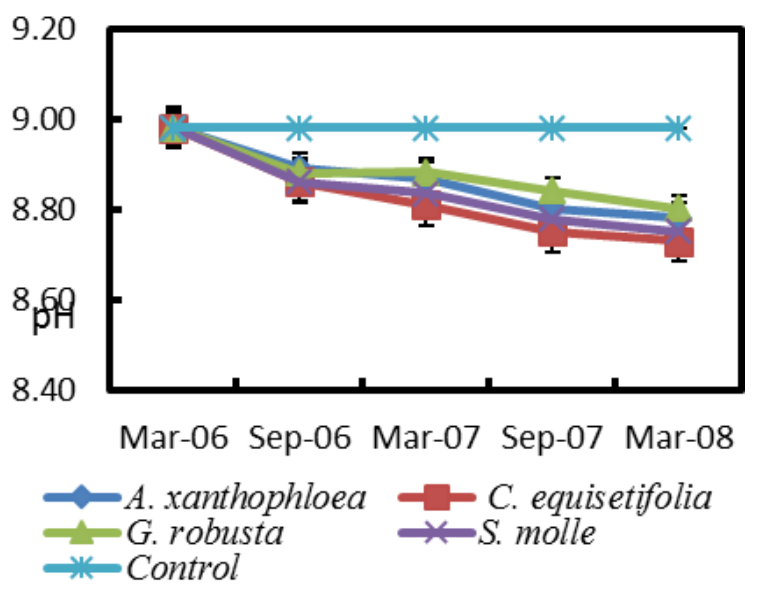

(b) $2 \mathrm{~m}$

Fig. 4 Timecourses of soil pH for 0-15 cm horizon at a distance of (a) $0.5 \mathrm{~m}$ and (b) $2 \mathrm{~m}$ from tree rows. Vertical bars show SED (Standard Error Deviation) values for comparing treatments. 


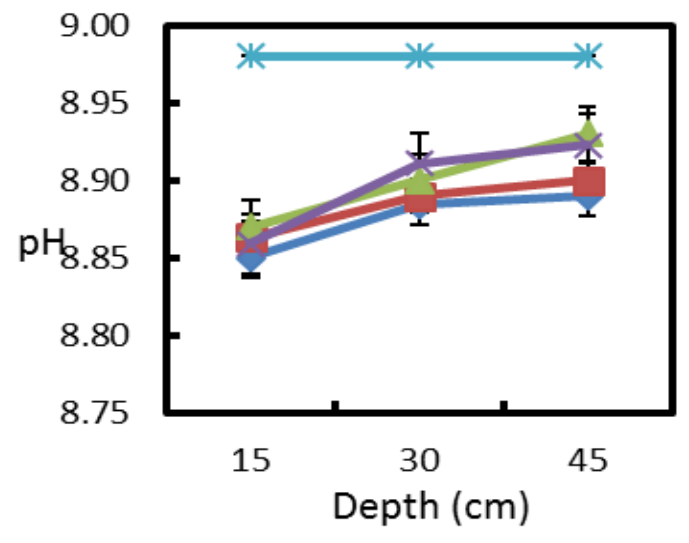

(a) Six months

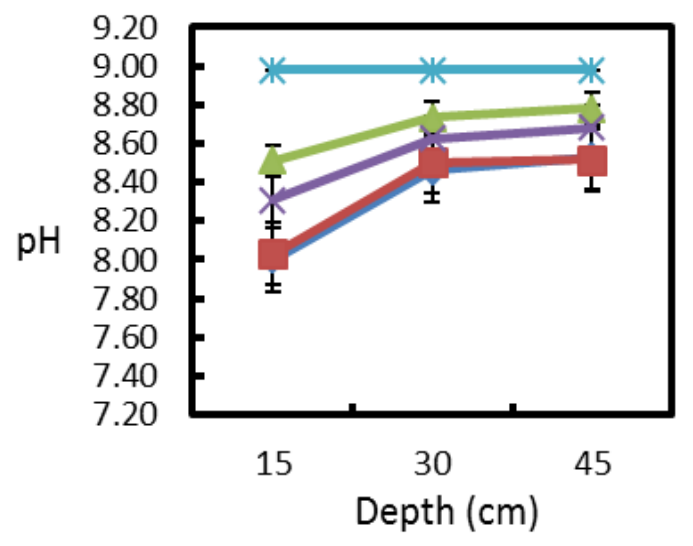

(b) Twenty four months

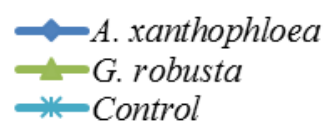
- C. equisetifolia $\because$ S. molle (n)

Fig. 5 Profile for soil $\mathrm{pH}$ in the treatments, at a distance of $0.5 \mathrm{~m}$ from the tree row.

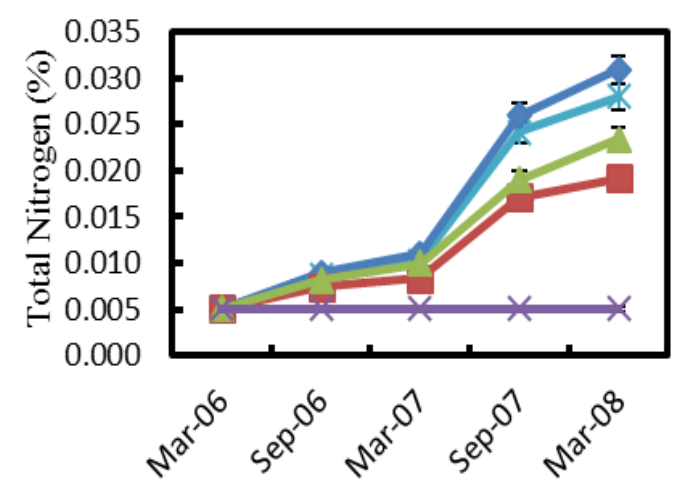

(a) $0.5 \mathrm{~m}$

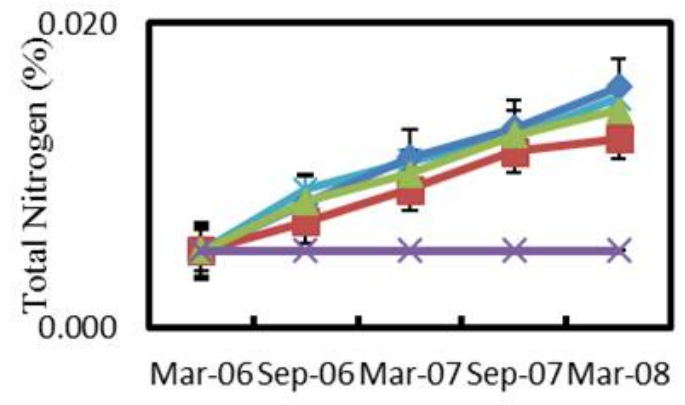

(b) $2.0 \mathrm{~m}$

\section{-A. xanthophloea $-G$. robusta Control}

Fig. 6 Timecourses of soil total nitrogen (\%) content for 0-15 cm horizon, at a distance of (a) $0.5 \mathrm{~m}$ and (b) $2.0 \mathrm{~m}$ from tree rows.

suggest that the organic matter from $A$. xanthophloea is probably more easily decomposed than that from $G$. robusta and $S$. molle.

\subsubsection{Soil Total Nitrogen}

Soil total nitrogen values recorded were $<0.03 \%$ under all tree species by the end of the observation period. These were below the $0.2 \%$ threshold construed as adequate for tropical soils [27], which demonstrated that soil fertility was low. A species effect on nitrogen was significant $(\mathrm{p}<0.01)$, with the soils collected from under $C$. equisetifolia from $0-15 \mathrm{~cm}$ horizon and at $0.5 \mathrm{~m}$ from the tree row recording relatively the highest levels of total nitrogen $(0.031 \%)$ as shown in Fig. 6. This was followed by $A$. xanthophloea $(0.028 \%)$. The nitrogen values were substantially lower under $S$. molle and $G$. robust $(0.023 \%$ and $0.019 \%$, respectively), and increased with distance from the trees as illustrated in Fig. 6.

No significant differences were detected between sampling depth or treatments, although the values of the upper layer $(0-15 \mathrm{~cm})$ were consistently higher than those of the lower $15-30 \mathrm{~cm}$ and $30-45 \mathrm{~cm}$ horizon as shown in Fig. 7. 


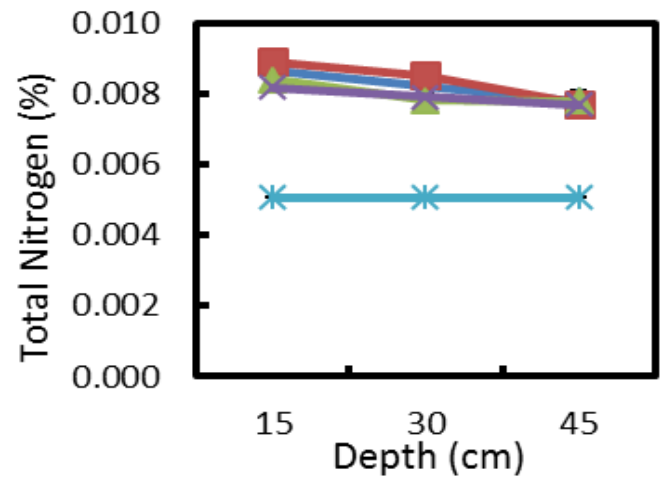

(a) Six months

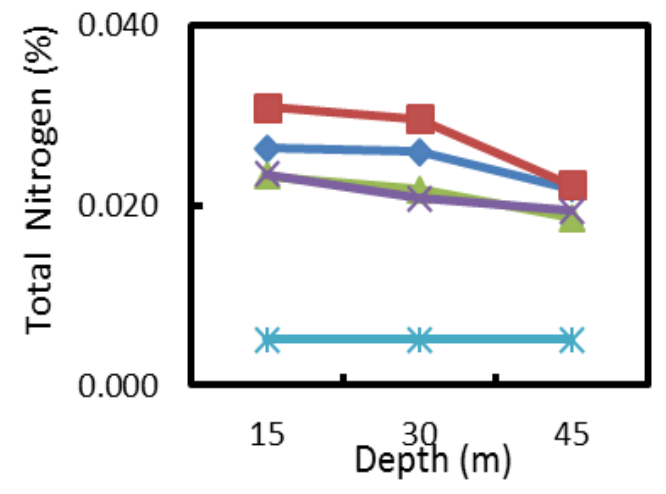

(b) Twenty four months

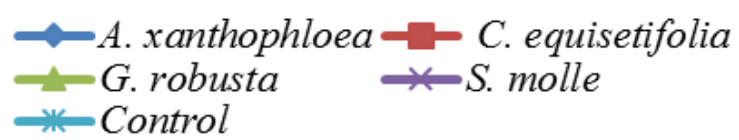

Fig. 7 Profile for soil total nitrogen (\%) in the treatments at a distance of $0.5 \mathrm{~m}$ from the tree row.

The low levels of nitrogen recorded may reflect the demand for nitrogen to support the microbial activity involved in litter decomposition [28]. The addition of leaf litter increases soil organic content, which might have induced rapid proliferation of microbial populations [26]. The relatively higher values of nitrogen recorded for soils under A. xanthophloea and C. equisetifolia could be due to the fact that these tree species are leguminous and have nitrogen-fixing capability. Mycorrhizas and cluster roots may be important components in nitrogen acquisition, supplementing nitrogen fixation as well as enabling uptake of other nutrients, as well as water [29]. However, it appears that these processes had not yet significantly affected soil nitrogen status, probably due to the short period of this study.

\subsubsection{Soil Total Phosphorus}

Soil phosphorus concentrations were moderate ranging from $44.15 \mathrm{ppm}$ to $21.33 \mathrm{ppm}$. Although not significant, by the end of the observation period, soils phosphorus was lower in the soils collected from under $A$. xanthophloea (25.97 ppm) and C. equisetifolia (21.33 ppm) than those from under G. robusta (33.89 ppm) and $S$. molle (31.80 ppm) and the values were relatively lower close to the tree row $(0.5 \mathrm{~m})$ and increased with distance from the trees as indicated in Fig. 8.

These differences can be explained by the observed difference in soil $\mathrm{pH}$ between the species, since $\mathrm{pH}$ is known to influence the status and availability of soil phosphorus [30, 31]. The predominant mechanism for low phosphorus availability on calcareous soils is the surface adsorptive reactions of phosphate ions with carbonate mineral [32]. A second possibly subsequent mechanism for low phosphorus availability is the formation of insoluble $\mathrm{CaPO}_{4}$ minerals [33], a reaction favoured by high soil $\mathrm{Ca}$ concentrations [34]. Micorrhizal associations may increase phosphorus uptake in calcareous soils [35].

\subsubsection{Soil Exchangeable Cations}

The effect of tree species on soil cation exchange capacity was examined. Relatively high concentrations of exchangeable calcium ranging from 22.17 to 70.17 me $\%$, sodium ranging from 2.59 to $88.89 \mathrm{me} \%$ and magnesium from 3.42 to 8.43 me \% were recorded. Potassium recorded average values ranging from 1.54 to $3.66 \mathrm{me} \%$ [21]. No significant differences between species or with distance were detected. However, at the end of the observation period, the soil concentration of all the exchangeable cations $(\mathrm{Ca}, \mathrm{Na}, \mathrm{Mg}$ and $\mathrm{K}$ ) had decreased. As observed in Figs. 9 and 10, these values were lowest close to the tree row $(0.5 \mathrm{~m})$ and increased with distance. This indicates that uptake of these nutrients by root activity is most pronounced close to the tree species [35]. 

Limestone Quarry at Athi River, Kenya

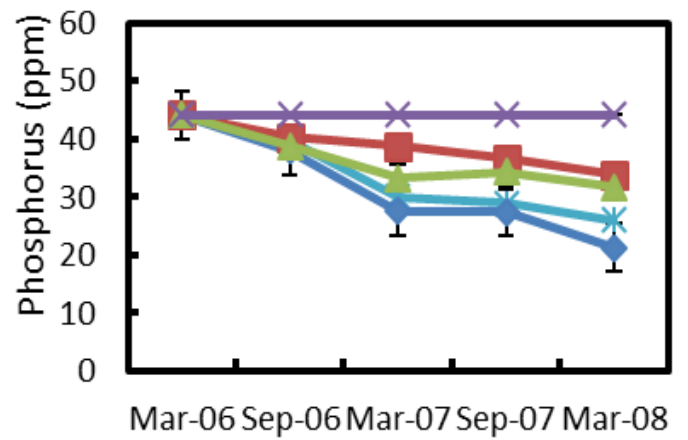

(a) $0.5 \mathrm{~m}$

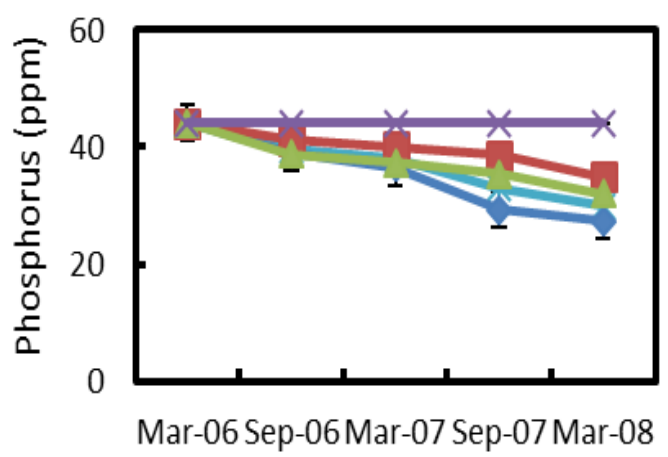

(b) $2.0 \mathrm{~m}$

\section{*-A.xanthophloea - G. robusta *Control}

$\sim$ C. equisetifolia - S. molle

Fig. 8 Timecourses of soil phosphorus (ppm) content for 0-15 cm horizon at a distance of (a) $0.5 \mathrm{~m}$ (b) $2.0 \mathrm{~m}$ from tree rows.
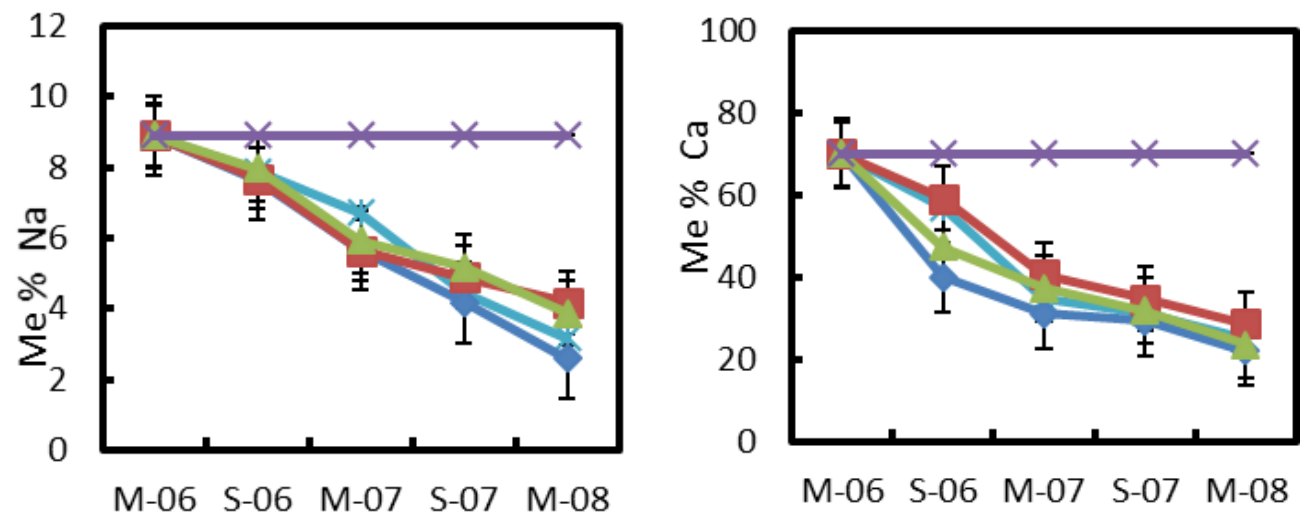

(a) $0.5 \mathrm{~m}$
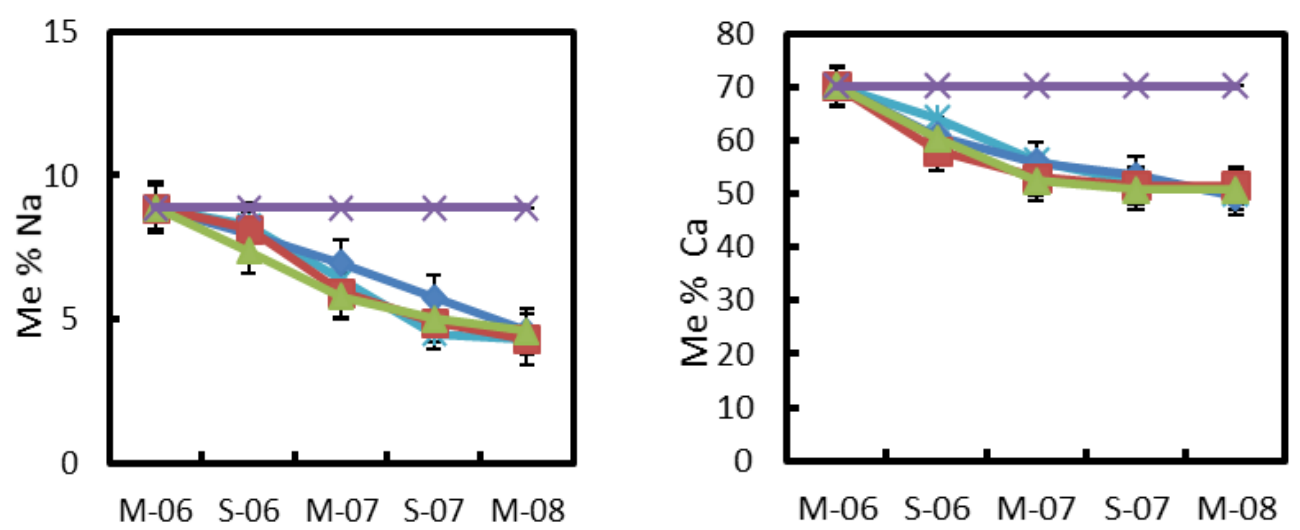

(b) $2.0 \mathrm{~m}$

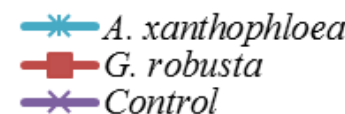

C. equisetifolia - S. molle $\because$ Control

Fig. 9 Timecourses of soil exchangeable cations ( $\mathrm{Na}$ and $\mathrm{Ca}$ ) content (me \%) for 0-15 $\mathrm{cm}$ horizon at a distance of (a) 0.5 m and (b) $2.0 \mathrm{~m}$ from tree rows. 

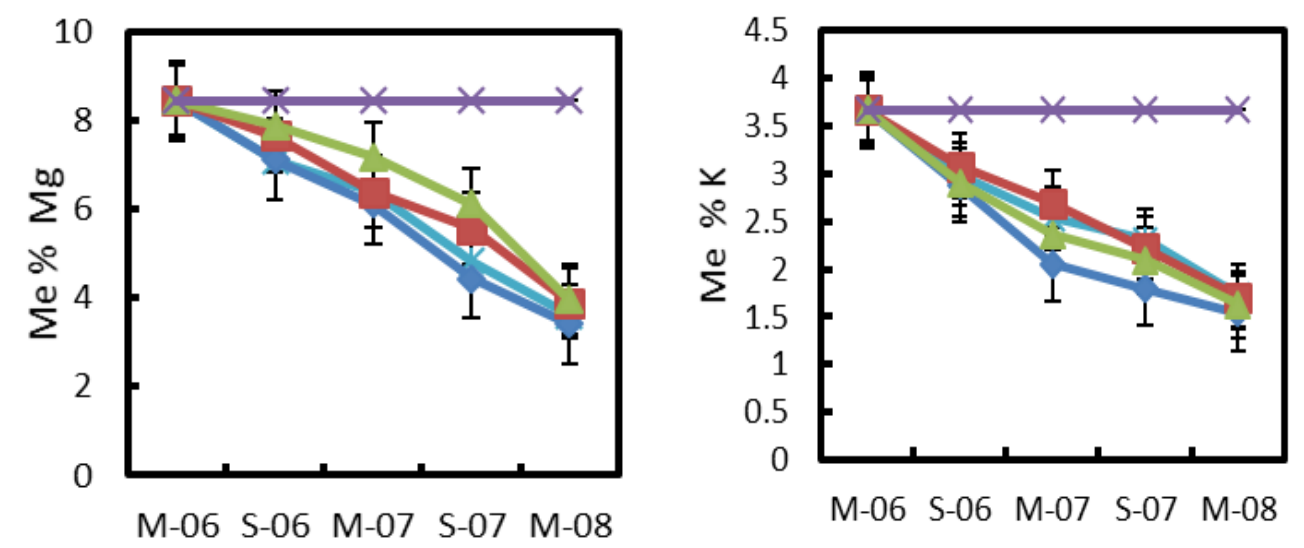

(a) $0.5 \mathrm{~m}$
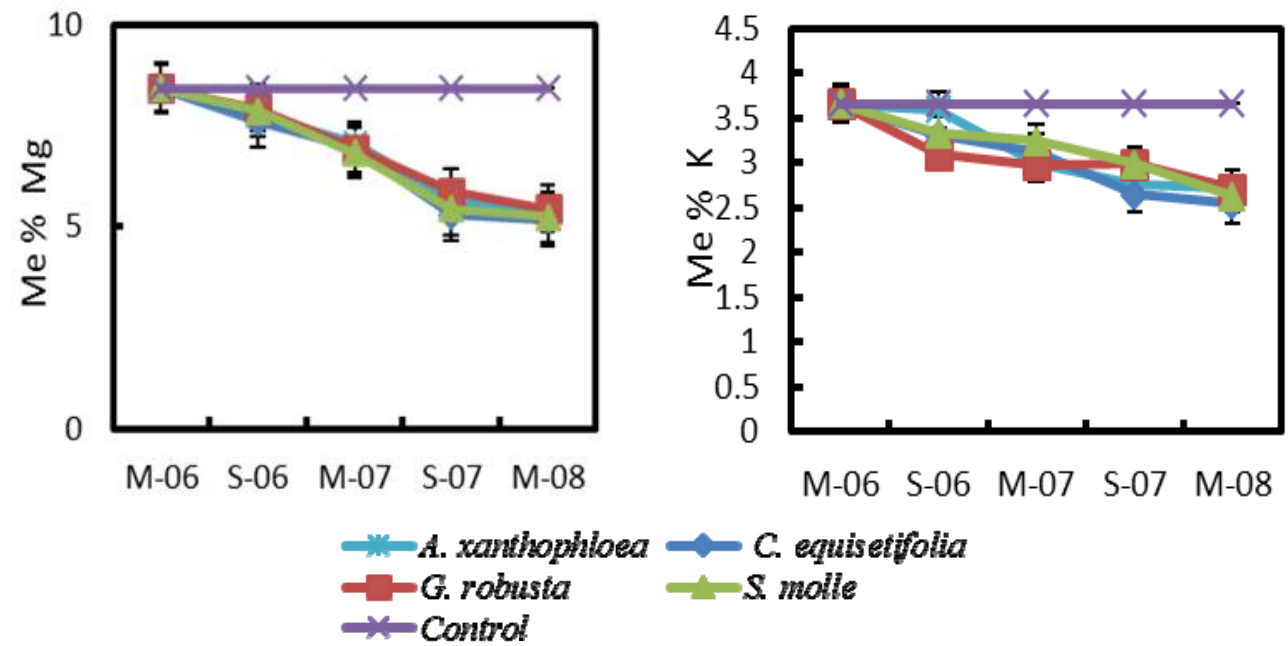

(b) $2.0 \mathrm{~m}$

Fig. 10 Timecourses of soil exchangeable cations ( $\mathrm{Mg}$ and $\mathrm{K}$ ) content (me \%) for 0-15 $\mathrm{cm}$ horizon at a distance of (a) $0.5 \mathrm{~m}$ and (b) $2.0 \mathrm{~m}$ from tree rows.

As it was also found in other studies, the exchangeable soil contents especially of calcium and magnesium decreased and exchangeable acidity increased with time and under cropping [36, 37]. In most soils, $\mathrm{Ca}$ and $\mathrm{Mg}$ are more susceptible to leaching than potassium [38]. Potassium is usually leached in much smaller quantities.

\section{Conclusion}

Although the mine waste used to backfill the quarry was of poor quality to support plant growth, the positive influence of all tree species on the soil chemical properties led to an increase in soil fertility. C. equisetofolia and A. xanthophloea showed the most significant improvements as evidenced from highest growth rates. There was a species-specific response from each tree type probably due to the different water-nutrient use strategies and growth rates. Trees should remain an essential feature of quarry rehabilitation in semi-arid environments due to their role in improving and maintaining the biophysical environment.

\section{References}

[1] Chaoji, A. 2009. "Case Study: Limestone Quarries of Gujarat Ambuja Cement Ltd. Kodinar, India. March 2, 2009." Eco-Restoration Of Limestone Quarries. Pugmarks Ecologix.

[2] Bradshaw, A. D., and Chadwick, M. J. 1980. The Restoration of Land: The Ecology and Reclamation of Derelict and Degraded Land. Univ. of California Press.

[3] Marrs, R. H., Roberts, R. D., Skeffington, R. A., and 
Bradshaw, A. D. 1981. "Ecosystem Development on Naturally Colonized China Clay Wastes: II. Nutrient Compartmention.” J. Ecol. 69: 163-9.

[4] Roberts, R. D., and Roberts. J. M. 1986. "The Selection and Management of Soils in Landscape Schemes." Ecology and Design in Landscape: 99-126.

[5] Sharma, S. C., and Roy, R. K. 1997. "Green Belt-An Effective Means of Mitigating Industrial Pollution." Indian J. Environmental Protection 17 (10): 724.

[6] EMCA. 1999. Environmental Management and Coordination Act 2000 the Laws of Kenya. Government Printers.

[7] Prach, K., and Pysek, P. 1994. "Spontaneous Establishment of Woody Plants in Central European Derelicts Sites and Their Potential for Reclamation." Restor. Ecol. 2 (3): 190-7.

[8] Bradshaw, A. 2000. "The Use of Natural Processes in Reclamation-Advantages and Difficulties." Landscape and Urban Planning 51 (2): 89-100.

[9] Smith, R. M., and Sobek, A. A. 1978. "Physical and Chemical Properties of Overburdens, Spoils, Wastes and New Soils." Reclamation of Drastically Disturbed Lands, 1st ed. ASA, CSSA and SSSA, Madison, WI: 149-72.

[10] Bailey. D., and Gunn. J. 1991. "Land Replication as an Approach to the Reclamation of Limestone Quarries." Land Reclamation: An End to Dereliction: 96-105.

[11] Tordof, G. M., Baker, A. J. M., and Willis, A. J. 2000. "Current Approaches to the Revegetation and Reclamation of Metalliferous Mine Wastes." Chemosphere 41 (1): 219-28.

[12] Coe, M., and Beentje, H. 1991. A Field Guide to the Acacias of Kenya. Oxford University Press.

[13] Anud, B. S. 2008. "Casuarina, a Salt Tolerant, Drought Resistant Tree for Converting Unfertile Lands to Fertile Lands.” Accessed December 10, 2009. http://www.lankanewspapers.com/news/2008/5/28015_sp ace.html.

[14] Iponga, D. M., Milton, S. J., and Richardson, D. M. 2008. "Superiority in Competition for Light: A Crucial Attribute Defining the Impact of the Invasive Alien Tree Schinus Molle (Anacardiaceae) in South African Savanna." Journal of Arid Environments 72 (5): 612-23.

[15] Ong, C. K., Black, C. R., Wallace, J. S., Khan, A. A. H., Lott, J. E., Jackson, N. A., et al. 2000. "Productivity, Microclimate and Water Use in Grevillea Robusta-based Agroforestry Systems on Hillslopes in Semi-arid Kenya." Agriculture, Ecosystems and Environment 80 (1): 121-41.

[16] APCM. 1977. East African Portland Cement Co. Ltd. Athi River Kunkur Reserves. Report No. GR/278/1977. Associated Portland Cement Manufacturers Limited, Geology Division. Kenya.

[17] Saggerson, E. P. 1991. Geology of the Nairobi Area (No.
98). Mines and Geology Department, Government of Kenya.

[18] Muthuri, C. W. 2004. "Impact of Agroforestry on Crop Performance and Water Resources in Semi-arid Central Kenya." Ph.D. thesis, Kenyatta University of Agriculture and Technology, Kenya, 292.

[19] Bashour, I. I., and Sayegh, A. H. 2007. Methods of Analysis for Soils of Arid and Semi-arid Regions. Food and Agriculture Organization of the United Nations, Rome.

[20] Olsen, S. R., and Sommers, L. E. 1982. "Phosphorus in Methods of Soil Analysis Part 2. Chemical and Microbiological Properties." Soil Science Society of America 9 (2): 403-30.

[21] Chege, A. M. 1982. "Internal Training Course for Kenya Soil Survey Staff, NAL, 21st June-3rd July 1982." Analytical Methods Used at NAL and the Interpretation of the Resultant Data. National Agricultural Laboratories.

[22] Landon, J. R. 2014. Booker Tropical Soil Manual: A Handbook for Soil Survey and Agricultural Land Evaluation in the Tropics and Subtropics. Routledge.

[23] Aguila, A. E. 2007. "Soil Fertility in Calcareous Tropical Soils from Yucatan, Mexico, and Villa Clara, Cuba, Affected by Land Use and Soil Moisture Eeffects." Ph.D. Dissertation, Georg August University, Gottingen, Germany.

[24] Ridley, A. M., Simpson, R. J., and White, R. E. 1998. "Nitrate Leaching under Phalaris, Cocksfoot and Annual Ryegrass Pastures and Implications for Soil Acidification." Crop and Pasture Science 50 (1): 55-64.

[25] Schroth, G. 1999. "A Review of Belowground Interactions in Agroforestry, Focusing on Mechanisms and Management Options." Agroforestry for Sustainable Land-Use Fundamental Research and Modelling with Emphasis on Temperate and Mediterranean Applications 43: 5-34. Springer Netherlands.

[26] Kumar, G., Hegde, K. R., and Luckins, C. B. 2001. "Decomposition and Nutrient Release Pattern of Leaf Litters of Mangium (Acacia Mangium Wild)." Indian Journal of Agroforestry 3 (1): 11-22.

[27] Lal, R., and Stewart, B. A. 1992. "Need for Land Restoration." Soil Restoration: 1-11. Springer-Verlag, New York.

[28] Anyango, S. O. 2011. "Sustainability of Dryland Afroforestry Systems in Eastern Kenya: Farmers' Perceptions, Physio-Ecological Factors and Landscape Patterns." Ph.D. thesis, Kenyatta University, Kenya, 166.

[29] Sprent, J. I. 1995. "Legume Trees and Shrubs in the Tropics: N2 Fixation in Perspective." Soil Biology and Biochemistry 27 (4-5): 401-7.

[30] Haggar, J. P., Warren, G. P., Beer, J. W., and Kass, D. 1991. "Phosphorus Availability under Alley Cropping 
Limestone Quarry at Athi River, Kenya

and Mulched and Unmulched Sole Cropping Systems in Costa Rica." Plant and Soil 137 (2): 275-83.

[31] Hands, M. R., Harrison, A. F., and Bayliss-Smith, T. 1995. "10 Phosphorus Dynamics in Slash-and-Burn and Alley Cropping Systems of the Humid Tropics." In Phosphorus in the Global Environment: Transfers, Cycles and Management, edited by Tiessen, H. John Wiley, New York, 155-70.

[32] Talibudeen, O. 1981. "Precipitation." In The Chemistry of Soil Processes, edited by Greenland, D. J., and Hayes, M. H. B. John Wiley and Sons, New York, 81-114.

[33] Marion, G. M., Cleve, K. V., Dyrness, C. T., and Black, C. H. 1993. "The Soil Chemical Environment along a Forest Primary Successional Sequence on the Tanana River Floodplain, Interior Alaska." Can. J. For. Res. 23 (5): 914-22.

[34] Gilmore, A. R., and Matis, D. S. 1981. "Effects of Past Agricultural Practices on the Soil Phosphorus System and Growth of Planted Pines 1.” Soil Sci. 131 (5): 313-9.
[35] Lapeyrie, F. F., and Chilvers, G. A. 1985. "An Endomycorrhiza-Ectomycorrhiza Succession Associated with Enhanced Growth of Eucalyptus Dumosa Seedlings Planted in a Calcareous Soil." New Phytol. 100 (1): 93-04.

[36] Juo, A. S., Franzluebbers, K., Dabiri, A., and Ikhile, B. 1995. "Changes in Soil Properties during Long-term Fallow and Continuous Cultivation after Forest Clearing in Nigeria." Agriculture, Ecosystems and Environment 56 (1): 9-18.

[37] Smyth T. J., and Cassel, D. K. 1995. "Synthesis of Long-term Soil Management Research on Ultisols and Oxisols in the Amazon." In Soil Management-Experimental Bases for Sustainability and Environmental Quality, edited by Lal, R., and Stewart, B. A. Lewis Publishers, Boca Raton, Florida, 13-59.

[38] Schroth, G., and Lehmann, J. 1995. "Contrasting Effects of Roots and Mulch from Three Agroforestry Tree Species on Yields of Alley Cropped Maize.” Agriculture, Ecosystems and Environment 54 (1): 89-101. 